\title{
The Tumor Microenvironment: The Making of a Paradigm
}

\author{
Isaac P. Witz
}

Received: 6 August 2009 /Accepted: 6 August 2009/Published online: 23 August 2009

(C) The Author(s) 2009. This article is published with open access at Springerlink.com

\begin{abstract}
What has been will be again, what has been done will be done again; there is nothing new under the sun

\section{(Ecclesiastes 1:9)}

Stephen Paget was the conceptual father of the role played by the Tumor Microenvironment (TME) in tumor progression. The focus of this essay is the developmental phase of the post Paget TME research. Attempts will be made to highlight some of the pioneering work of scientists from the late sixties through the eighties of last century who laid the foundations for the contemporary scientific achievements of TME research but whose ground breaking studies are rarely cited. This review should serve as a small tribute to their great work.
\end{abstract}

Keyword Tumor microenvironment

The tumor microenvironment (TME) is a pivotal factor in tumorigenesis and especially in tumor progression and the pathogenesis of cancer is largely dependent on its interactions with microenvironmental components. This paradigm should be clear to every cancer researcher, as it is for the participants of the "5th International Conference on Tumor Microenvironment: Progression, Therapy \& Prevention".

This presentation attempts to highlight certain key events of the developmental phase of the "tumor microenvironment" concept which lead to the contemporary achieve-

I. P. Witz $(\square)$

Faculty of Life Sciences, Department of Cell

Research \& Immunology, Tel Aviv University,

Ramat Aviv, Tel Aviv 69978, Israel

e-mail: ipwitz@post.tau.ac.il ments of this research area. The essay which is not intended to serve as a comprehensive review will conclude with a biased view as to challenges facing TME researchers.

Stephen Paget laid the foundations of the TME research area by formulating the seed and soil theory. Paget's concept lay dormant for many years. Only in the mid seventies of the 20th century and onwards did a relatively small group of people revisit Paget's ideas [1-9]. Auerbach [10], for example, cites Paget: "The best work in the pathology of cancer is done by those studying the nature of the seed. They are like scientific botanists; and he who turns over the records of cases of cancer is only a ploughman, but his observations of the properties of the soil may also be useful". Auerbach then expresses his own views on cancer researchers who study the tumor microenvironment: "Those individuals who study the properties of the host environment should not be ignored. Not only are the observations of the 'soil' useful, they provide essential information without which we will not be able to understand the nature of the metastatic process".

\section{From Infancy to Young Adulthood}

The post Paget research of the TME was initiated by two non-interacting groups of research pioneers: immunologists and scientists focusing on angiogenesis. Until the late seventies or early eighties, these two research groups performed by far the most significant TME research.

Most of the early studies on the immune microenvironment of cancer focused on the characterization and functions of cellular and humoral immune components in the tumor microenvironment [11-36] These studies established that immunocytes including $\mathrm{T}$ cells [23, 32], B cells 
$[14,17]$, NK cells $[24,31]$ and macrophages $[19,20,26$, $27,29,33,35,36]$ have the capacity to infiltrate solid tumors in humans and in animals. Other studies demonstrated that immunoglobulins (Ig) and complement components could be detected in the microenvironment of solid tumors. Tumor cells in humans, rats and mice were found to be coated with $\operatorname{Ig}[11,12,18,25,34]$. This coat was composed either of anti tumor antibodies bound to the tumor cells via the antigen binding site (in an antibodyepitope interaction) [37] or of Ig (mainly $\operatorname{IgG}$ ) bound to epithelial or mesenchymal tumor cells via Fc receptors (FcR) expressed by such tumor cells [38]. The tumorassociated FcR was a promalignancy factor [39]. Microenvironmental factors were found to regulate the expression of the FcR expressed by the tumor cells [40].

The state of the art with respect to the immune microenvironment of cancer was evaluated by leading cancer immunologists in a UICC-supported workshop on "In-Situ Expressions of Tumor Immunity" that took place in 1978 in Tel Aviv, Israel. Some of the participants of the 1978 meeting participate also in the Versailles Conference.

The proceedings of the Tel Aviv meeting were published [41]. Most of the presentations dealt with the characterization of immune components (cells and molecules) found at the sites of solid tumors and on their functional activities.

The bottom line of the workshop's deliberations was that the immune components that localized in the TME were relatively deficient in anti tumor activities in comparison to similar components originating from systemic sites. Some tumor-localizing components, especially tumor-localizing antibodies even enhanced tumor development.

The other group of TME pioneers led by Judah Folkman focused on angiogenesis. They realized very early that tumor proliferation was dependent upon blood supply and that the interactions of tumor and endothelial cells initiated and drove this process. Angiogenic factors were identified in various types of tumors and the possibility was raised that inhibiting such factors or their interaction with endothelial cells will be of clinical benefit to cancer patients [42-59].

With the exception of research on the immune microenvironment and angiogenesis, the areas that today occupy the forefront of TME research were essentially not represented in the scientific arena until the early-mid eighties. However, from there on, the research field of the TME moved forward, expanding and enlarging its scope to new frontiers.

Among the topics that were explored in the early eighties were interactions between the extracellular matrix (ECM) and tumor cells [60-64] and between fibroblasts and tumor cells [65-67]. These and other studies published at that time indicated that tumor-ECM or tumor-fibroblast interactions may exert either anti tumor effects or the opposite, namely pro malignancy effects.
Rudolph Virchow's paradigm that inflammation contributes to carcinogenesis and tumor progression [68] has developed into one of the major and most important aspects of the TME area. It was demonstrated that inflammatory cells (mainly macrophages) as well as proinflammatory molecules such as cytokines and chemokines whose physiologic function is to constitute a firewall against infectious agents, are causally involved in the initiation of certain types of cancer (inflammation-linked cancers) or in tumor progression of essentially all types of cancer $[69,70]$. As mentioned above, several studies from the seventies of last century reported that mononuclear cells infiltrate solid tumors $[19$, $20,26,27,29,33,35,36]$. It took several years to establish that such cells are heavily involved in the pro malignancy functions of cancer-linked inflammation [69-72].

However, many, if not most components of the TME may, under certain circumstances, exert anti malignancy activities whereas under different circumstances, they exert pro malignancy effects [73]. Tumor infiltrating macrophages are no exception [74-78]. The contemporary studies on tumor infiltrating macrophages tend, however, to stress their pro malignancy effects rather than the anti malignancy functions of these cells [71, 79-86].

Angiogenesis, the immune context of tumors, the interrelationships of tumor cells with fibroblasts, components of the ECM and pro-inflammatory mediators are among the cutting edge topics of contemporary TME research. It is important to realize that the pioneering studies in these areas were undertaken at a time in which cancer genetics dominated the scene.

The discoveries made in cancer genetics in the three decade period from the early seventies until the end the nineties are undoubtedly the golden era of this research domain. The prevailing and dominating concept at that time was that genetic alterations in oncogenes and tumor suppressor genes are both necessary and sufficient to initiate tumorigenesis and drive tumor progression.

What, if any was the relationship between cancer geneticists and the "individuals who study the properties of the host environment" (to use Auerbach's words)? Obviously both groups focused on different aspects of malignancy, holding, most probably opposing views as to the relative importance of cancer genes or of the TME to the pathophysiology of cancer. There is no indication that a direct or indirect debate between those groups took place. Seemingly the concept that assigns to cancer genes the primary role in carcinogenesis was in no conflict with the concept attributing site specific metastasis to the outcome of interactions between the seed (the tumor) and the soil (the TME). None the less, armed with cutting edge and sophisticated technologies the cancer geneticists established themselves as strong and influential policy makers while the microenvironmentalists, generating "uninteresting" data 
and describing "epiphenomena" were not part of the main stream of cancer research at that time.

The nineties of last century marked a change in this attitude. The contribution of the TME to cancer progression started to be recognized by an increasing number of cancer researchers.

A primary factor responsible for this development was the revolution in biomedicine brought about by the identification and functions of molecules involved in signal transduction and the elucidation of signaling pathways [87-105].

Armed with novel knowledge and technologies it was demonstrated that gene expression in tumor cells as well as in non-tumor cells residing in the TME, is regulated by microenvironmental factors [e.g., 106, 107]. Assessment of the relative contribution of microenvironmental factors versus genetic lesions to the shaping of the malignancy phenotype of tumor cells indicated that the latter are not the sole and exclusive driver of malignancy.

For example, it was demonstrated that oncogenes and a microenvironmental factor (hypoxia) synergistically modulated VEGF expression in tumor cells and impacted angiogenesis [108]. Another study, performed in my lab, showed that the microenvironment played an important role in tumorigenesis. The tumorigenicity of polyoma virustransformed BALB/C $3 \mathrm{~T} 3$ cells in syngeneic mice depended on the microenvironment in which these cells were grown rather than on the content of the polyoma middle T oncogene [109].

Another important factor that helped to bring TME to the fore front of cancer research was that notable scientists from other domains of cancer research joined the ranks of the tumor microenvironmetalists.

Mina Bissell, a noted developmental biologist was early in realizing that similarly to the dependence of developmental processes on the microenvironment, also tumor progression is dependent upon the microenvironment [110]. In another article Bissell's group wrote "Several lines of evidence now support the contention that the pathogenesis of breast cancer is determined (at least in part) by the dynamic interplay between the ductal epithelial cells, the microenvironment, and the tissue structure (acini). Thus, to understand the mechanisms involved in carcinogenesis, the role of the microenvironment (ECM as well as the stromal cells) with respect to tissue structure should be considered and studied" [111]. Bissell and her colleagues concluded: "The current dominant paradigm wherein multiple genetic lesions provide both the impetus for, and the Achilles heel of, cancer might be inadequate to understand cancer as a disease process" [112].

Holding a similar view, Ruth Sager, a leader in cancer genetics wrote in one of her last articles before her untimely departure that the oncogenes and tumor suppressor genes known at that time, "affect principally cell cycle regulation. None are known to affect invasion or metastasis". These genes "do not begin to account for the diversity of cancer phenotypes" [113]. Sager recommended shifting the focus from DNA to RNA i.e. to expression genetics of cancer. She also advocated the "grouping of cancer genes into two classes: class I genes are mutated or deleted, whereas class II genes are not altered at the DNA level. Rather they affect the phenotype by expression changes". Class 2 cancer genes are those controlled by the microenvironment. A similar view was expressed, 7 years later, by Vogelstein and Kinzler [114]. They indicated that the late stages of cancer are not specifically associated with abnormalities in cancer genes (i.e. oncogenes and tumor suppressor genes).

The multitude of microenvironmental factors, their enormous activity spectrum and the complexity of their intermolecular cross talk obviously requires an interactive and interdisciplinary exchange between researchers engaged in this research domain. A group of investigators thought to promote such interactions at the international level by organizing meetings dedicated exclusively to TME. The first "International Conference on Tumor Microenvironment: Progression, Therapy, Prevention" was held in Israel on the shore of the Sea of Galilee in 1995. Among the 250 participants were several who participate in the present conference. The Sea of Galilee meeting was a truly multidisciplinary event where the focal issue, the TME, was approached and discussed thoroughly by specialists from a wide spectrum of biomedical sciences.

The 1995 conference was the impetus to establish the International Cancer Microenvironment Forum (ICMF). The forum was founded by an international group of about twenty cancer researches from ten countries. These scientists who were joined a few years later by additional scientists became the "charter member" group of ICMF.

Informal charter member meetings were held in London (1997-hosted by Frances R. Balkwill, Imperial Cancer Research Fund); Pittsburgh, (1999-hosted by Theresa L. Whiteside and Ronald B. Herberman, University of Pittsburgh Cancer Institute), San Sebastian, (2003-hosted by Fernando Vidal-Vanaclocha, Basque Country University, School of Medicine) and in Safed (2008-hosted by the Israeli Charter Members). Present in these meetings were charter members and some invited guests. These informal meetings were devoted mainly to discussions on recent results of studies connected with the TME.

One of the resolutions of the 2003 San Sebastian charter member meeting was to upgrade ICMF. The International Cancer Microenvironment Society (ICMS) was thus established. The new society thrives to constitute a significant driving force towards the development of novel, microenvironment-related cancer therapy modalities. 
The second and the third "Tumor Microenvironment" conferences were held in Baden, Austria (2002) and in Prague, Czech Republic (2004). The fourth "Tumor Microenvironment" conference was held in Florence, Italy in 2007 in a joint venture with the American Association for Cancer Research. All four meetings met, in full, the intentions of the organizers to create a friendly forum that promotes a critical review of novel basic findings and of innovative clinical studies pertaining to the TME.

The scientific seeds planted in the TME field in the early seventies of the twentieth century, bore fruit which ripened about $10-15$ years ago. The TME is increasingly recognized by cancer researchers as a pivotal factor in tumor progression and as a promising venue for drug discovery. Indeed many of the novel cancer therapy modalities interfere with tumor-microenvironment interactions. A point in case is drugs that inhibit signals delivered to tumor cells by microenvironmental growth factors via the corresponding receptors [115-133].

The influx of highly capable and excellent scientists from several domains of biosciences into the TME field contributed significantly to the increased popularity of this field and to its becoming an innovative and stimulating research area.

The establishment also fulfilled its share in the acceptance of the TME as an important factor in cancer development and progression.

Compelling examples for this are statements by a former Director of NCI, Dr. Andrew C. von Eschenbach. In his update from December 2, 2003, he wrote: "the cancer cell is only part of the story in cancer development. Mounting evidence now suggests that a cancer cell interacts with its local and systemic microenvironments, and each profoundly influences the behavior of the other. These tumor-host interactions permit, and even encourage, cancer progression. Two years ago, the National Cancer Institute identified the tumor microenvironment as a priority research area in an effort to expand our knowledge of the cells and factors that normally populate the microenvironment as well as to advance our understanding of how these microenvironment components interact with tumor cells".

Additional events that increased the impact of the TME research area were:

- The launching by the National Cancer Institute, NIH, of the Tumor Microenvironment Network initiative (TMEN) with the funding of ten Programs (http:// tmen.nci.nih.gov/).

- The introduction of topics related to cancer microenvironment to the FP7-Health-2007 program of the European Commission.

- The establishment of the TME Working Group by the American Association for Cancer Research (http://www. aacr.org/home/scientists/working-groups-task-forces/tu mor-microenvironment-working-group.aspx).

- A huge increase in the number of publications dealing with TME. Based on PubMed data, an increase of more than eight fold occurred in the 14 year period from 1995 to 2008 (Fig. 1).

- A very large number of review articles on various aspects of the TME that appeared recently. Only a small minority out of scores of such articles is cited below [73, 134-156].

- The inclusion of "Tumor Microenvironment" as a major topic in leading international conferences.

- The recent founding of the official journal of the International Cancer Microenvironment Society- "Cancer Microenvironment" (http://www.springer.com/biomed/ cancer/journal/12307).

It is very difficult, if not impossible, to summarize, in a single article, the state of the art with respect to each of the interaction types between the tumor and its microenvironment. Indeed it was not the aim of this article to do so. None the less an attempt will be made to draw some general hallmarks characterizing most instances of tumormicroenvironment interactions.

Before doing so, it may be useful to point out the conceptual differences between Paget's perception of the role of the microenvironment in tumor progression (Paget's focus was on site specific metastasis) and the modern paradigm. Paget assigned to the microenvironment a role of promoter/inhibitor of tumor cell proliferation at specific secondary sites. According to his hypothesis the microenvironment at these sites either supports metastasis by supplying growth promoting factors or alternatively inhibits metastasis by growth inhibitors. On the other hand the contemporary post Paget perception assigns to the TME an

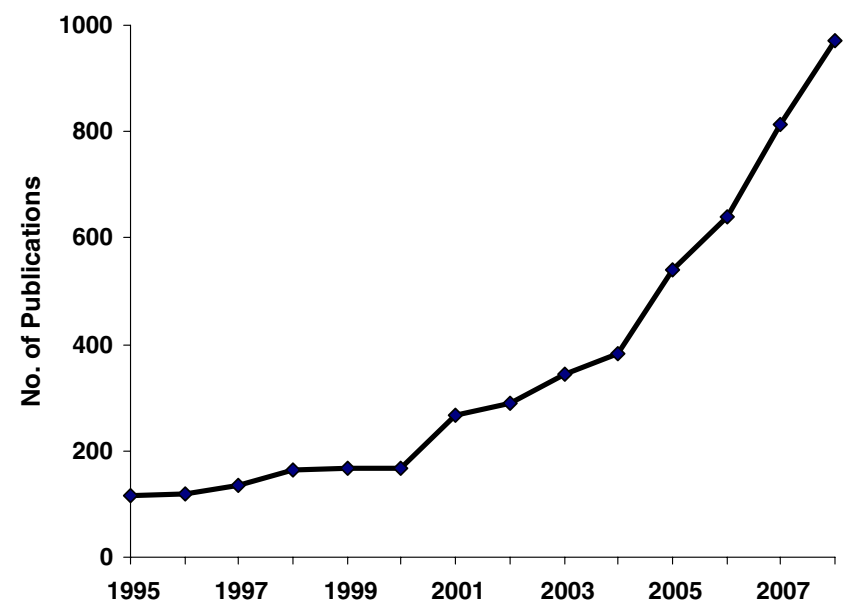

Fig. 1 Number of TME-related publications during the period: 1995-2008 
inductive, adaptive and selective function: The tumor is directed into one or several possible molecular evolution pathways by signals originating in native and/or modified microenvironmental factors. Many of these pathways may lead to metastasis.

The TME may be characterized as follows:

1. The molecular composition of the TME is established jointly by tumor cells as well as by resident and infiltrating non-tumor cells.

2. Interactions of cancer cells with components of their microenvironment are crucial determinants in the decision making process determining if cancer cells will progress towards metastasis, if they will stay dormant or if they will disappear altogether.

3. Tumor-microenvironment interactions are bidirectional. Each of the interaction partners is capable of regulating gene expression in the other partner, or of exerting selective pressures on it. Each interaction partner thus shapes the phenotype of the other partner.

4. Certain tumor-microenvironment interactions may initiate and drive circular chains of tumor progressionenhancing events known as vicious cycles. In a typical vicious cycle the tumor manipulates non-tumor cells in the microenvironment and harnesses them to support its progression.

5. Certain, possibly many, microenvironmental factors play opposing roles in tumor progression by either promoting or alternatively antagonizing this process. Several variables such as the tumor type, the progression stage of the tumor, the status of certain receptors on tumor cells determine if these factors will exert either pro or anti malignancy activities.

6. Many tumor-microenvironment interactions promote tumor progression.

\section{Destinations}

Alice: Would you tell me, please, which way I ought to go from here?

The Cat: That depends a good deal on where you want to get to

Alice: I don't much care where

(Lewis Carroll-Alice in Wonderland)

The cancer research community, In contrast to Alice, knows where it wants to get to: It thrives to cure cancer and, hopefully prevent it.

Most of us would agree that the tumor has the capacity to shape the phenotype of non tumor cells in the microenvironment and to harness them to support its progression. Accordingly the approaches to meet the goal of cancer cure have undergone a significant change. Cancer therapy has shifted from exclusively targeting only the tumor to targeting three components: the tumor, its accomplices and accessories in the microenvironment as well as the interactions between them.

Numerous interactions between tumor cells and the microenvironment have been identified. These interactions may either restrain tumor progression or, more often, promote it. Is any one of the pro-malignancy interactions sufficient for metastasis or do tumor cells need all (or a subgroup) of them in order to progress? Is there a hierarchy of interactions that drive tumor progression? In other words, are there more important and less important interactions with respect to metastasis formation? Are we able to identify those interactions that play the most important roles in tumor progression and should be thus, therapeutically targeted? Do different interactions integrate through intertwined signaling cascades or through shared molecules to a single interaction network?

It is up to the TME community to provide answers to these questions which are obviously of enormous importance in the design of future cancer therapy drugs. However, the immense multitude of candidate microenvironmental factors, the extreme complexity of the signaling cascades operating in the microenvironment, the intricacy of the interactive crosstalk between these cascades, and finally tumor heterogeneity, pose a formidable challenge for those of us attempting to provide solutions to these questions.

To overcome these challenges we need to provide a comprehensive overall picture of the various molecular cross-talks between tumor cells and their microenvironment leading to and driving tumor progression. One of the first steps in our attempts to comprehend the big picture of tumor progression is to realize that single molecules or single signaling pathways are just solitary components of an immense network. This realization should lead to the abandonment of reductionism (which, I am afraid, is a difficult mission under the present culture of conducting science and its funding) and to the employment of approaches used in Systems Biology [157-159].

In the interim tumor microenvironmentalists may contribute to cancer therapy by:

1. Accumulating additional data on mechanisms of tumormicroenvironment interactions

2. Finding ways to target those interactions with the highest probability of influencing tumor progression (expected are numerous opinions as to what these interactions might be...)

3. Reversing the pro-malignancy effects of the microenvironment.

These goals are achievable. 
Acknowledgements I am indebted to the former and present members of my team for their devotion, talent, creativity, and diligence.

The following foundations and individuals are thanked for generous grant support: The Dr. Miriam and Sheldon G. Adelson Medical Research Foundation (Needham, MA, USA), The Ela Kodesz Institute for Research on Cancer Development and Prevention, Tel Aviv University; The Fainbarg Family Fund (Orange County, CA, USA); Bonnie and Steven Stern (New York, NY, USA), The Fred August and Adele Wolpers Charitable Fund (Clifton, NJ, USA), Natan Blutinger (West Orange, NJ, USA), Arnold and Ruth Feuerstein (Orange County, CA, USA), The Pikovsky Fund (Jerusalem, Israel); and James J. Leibman and Rita S. Leibman Endowment Fund for Cancer Research (New York, NY, USA).

Open Access This article is distributed under the terms of the Creative Commons Attribution Noncommercial License which permits any noncommercial use, distribution, and reproduction in any medium, provided the original author(s) and source are credited.

\section{References}

1. Onuigbo WI (1975) Human model for studying seed-soil factors in blood-borne metastasis. Arch Pathol 99:342-343

2. Hart IR, Fidler IJ (1980) Role of organ selectivity in the determination of metastatic patterns of B16 melanoma. Cancer Res 40:2281-2287

3. Hart IR (1982) 'Seed and soil' revisited: mechanisms of sitespecific metastasis. Cancer Metastasis Rev 1:5-16

4. Weiss L, Voit A, Lane WW (1984) Metastatic patterns in patients with carcinomas of the lower esophagus and upper rectum. Invasion Metastasis 4:47-60

5. Weiss L, Harlos JP, Torhorst J et al (1988) Metastatic patterns of renal carcinoma: an analysis of 687 necropsies. J Cancer Res Clin Oncol 114:605-612

6. Nicolson GL (1988) Organ specificity of tumor metastasis: role of preferential adhesion, invasion and growth of malignant cells at specific secondary sites. Cancer Metastasis Rev 7:143-188

7. Pauli BU, Lee CL (1988) Organ preference of metastasis. The role of organ-specifically modulated endothelial cells. Lab Invest 58:379-387

8. Cher ML (2001) Mechanisms governing bone metastasis in prostate cancer. Curr Opin Urol 11:483-488

9. Fidler IJ (2003) The pathogenesis of cancer metastasis: the 'seed and soil' hypothesis revisited. Nat Rev Cancer 3:453-458

10. Auerbach R (1988) Patterns of tumor metastasis: organ selectivity in the spread of cancer cells. Lab Invest 58:361-364

11. Ran M, Witz IP (1972) Tumor-associated immunoglobulins. Enhancement of syngeneic tumors by IgG2-containing tumor eluates. Int J Cancer 9:242-247

12. Witz IP (1973) The biological significance of tumor-bound immunoglobulins. Curr Top Microbiol Immunol 61:151-171

13. Vánky F, Trempe G, Klein E et al (1975) Human tumor-lymphocyte interaction in vitro: blastogenesis correlated to detectable immunoglobulin in the biopsy. Int J Cancer 16:113-124

14. Richters A, Kaspersky CL (1975) Surface immunoglobulin positive lymphocytes in human breast cancer tissue and homolateral axillary lymph nodes. Cancer 35:129-133

15. Jondal M, Klein G (1975) Classification of lymphocytes in nasopharyngeal carcinoma (NPC) biopsies. Biomedicine 23:163-165

16. Haskill JS, Yamamura Y, Radov L (1975) Host responses within solid tumors: non-thymus-derived specific cytotoxic cells within a murine mammary adenocarcinoma. Int J Cancer 16:798-809
17. Catalona WJ, Mann R, Nime F et al (1975) Identification of complement-receptor lymphocytes (B cells) in lymph nodes and tumor infiltrates. J Urol 114:915-921

18. Zeromski J, Gorny MK, Wruk M et al (1975) Behaviour of local and systemic immunoglobulins in patients with lung cancer. Int Arch Allergy Appl Immunol 49:548-563

19. Hersh GM Mavligit, Gutterman JU et al (1976) Mononuclear cell content of human solid tumors. Med Pediatr Oncol 2:1-9

20. Russel SW, Doe WF, Cochrane CG (1976) Number of macrophages and distribution of mitotic activity in regressing and progressing Moloney sarcomas. J Immunol 116:164-166

21. Klein E, Becker S, Svedmyr E et al (1976) Tumor infiltrating lymphocytes. Ann. NY Acad. Sci 276:207-216

22. Klein E, Svedmyr E, Jondal M et al (1977) Functional studies on tumor-infiltrating lymphocytes in man. Isr J Med Sci 13:747-752

23. Brubaker DB, Whiteside TL (1977) Localization of human T lymphocytes in tissue sections by a rosetting technique. Am J Pathol 88:323-332

24. Vose BM, Vanky F, Argov S et al (1977) Natural cytotoxicity in man: activity of lymph node and tumor-infiltrating lymphocytes. Eur J Immunol 7:353-357

25. Witz IP (1977) Tumor-bound immunoglobulins: in situ expressions of humoral immunity. Adv Cancer Res 25:95148

26. Stewart CC, Beetham KL (1978) Cytocidal activity and proliferative ability of macrophages infiltrating the EMT6 tumor. Int J Cancer 22:152-159

27. Vose BM (1979) Functional activity of human tumor-infiltrating macrophages. Adv Exp Med Biol 114:783-787

28. Vose BM, Moore M (1979) Suppressor cell activity of lymphocytes infiltrating human lung and breast tumours. Int $\mathrm{J}$ Cancer 24:579-585

29. Svennevig JL, Svaar H (1979) Content and distribution of macrophages and lymphocytes in solid malignant human tumours. Int J Cancer 24:754-758

30. Klein E, Vanky F, Galili U et al (1980) Separation and characteristics of tumor-infiltrating lymphocytes in man. Contemp Top Immunobiol 10:79-107

31. Moore K, Moore M (1979) Systemic and in-situ natural killer activity in tumour-bearing rats. Br J Cancer 39:636-647

32. Yron I, Wood TA Jr, Spiess PJ et al (1980) In vitro growth of murine $\mathrm{T}$ cells. V. The isolation and growth of lymphoid cells infiltrating syngeneic solid tumors. J Immunol 125:238245

33. Totterman TH, Parthenais E, Hayry P et al (1980) Cytological and functional analysis of inflammatory infiltrates in human malignant tumors. III. Further functional investigations using cultured autochthonous tumor cell lines and freeze-thawed infiltrating inflammatory cells. Cell Immunol 55:219-226

34. Ran M, Yaakubowicz M, Amitai O et al (1980) Tumor-localizing lymphocytotoxic antibodies. Contemp Top Immunobiol 10:191-211

35. Talmadge JE, Key M, Fidler IJ (1981) Macrophage content of metastatic and nonmetastatic rodent neoplasms. J Immunol 126:2245-2248

36. Haskill S, Becker S, Fowler W et al (1982) Mononuclear-cell infiltration in ovarian cancer. I. Inflammatory-cell infiltrates from tumour and ascites material. Br J Cancer 45:728-736

37. Ran M, Klein G, Witz IP (1976) Tumor-bound immunoglobulins. Evidence for the in vivo coating of tumor cells by potentially cytotoxic anti-tumour antibodies. Int $\mathrm{J}$ Cancer 17:90-97

38. Braslawsky GR, Yaackubowicz M, Frensdorff A et al (1976) Receptors for immune complexes on cells within a nonlymphoid murine tumor. J Immunol 116:1571-1578

39. Zusman T, Gohar O, Eliassi H et al (1996) The murine Fcgamma ( $\mathrm{Fc}$ gamma) receptor type II $\mathrm{B} 1$ is a tumorigenicity- 
enhancing factor in polyoma-virus-transformed 3T3 cells. Int $\mathrm{J}$ Cancer 65:221-229

40. Ran M, Katz B, Kimchi N et al (1991) The in-vivo acquisition of Fc $\gamma$ RII expression on polyoma virus transformed cells derived from tumors of long latency. Cancer Res 51:612-618

41. Witz IP, Hanna MG Jr (eds) (1980) Contemp Top Immunobiol, 10. In situ expression of tumor immunity. Plenum, New York

42. Folkman J, Merler E, Abernathy C et al (1971) Isolation of a tumor factor responsible for angiogenesis. J Exp Med 133:275288

43. Folkman J (1971) Tumor angiogenesis: therapeutic implications. N Engl J Med 285:1182-1186

44. Brem S, Cotran R, Folkman J (1972) Tumor angiogenesis: a quantitative method for histologic grading. J Natl Cancer Inst 48:347-356

45. Folkman J (1972) Anti-angiogenesis: new concept for therapy of solid tumors. Ann Surg 175:409-416

46. Blumberg N (1974) Tumor angiogenesis factor. Speculations on an approach to cancer chemotherapy. Yale J Biol Med 47:71-81

47. Folkman J (1974) Tumor angiogensis: role in regulation of tumor growth. Symp Soc Dev Biol 30:43-52

48. Folkman J (1974) Tumor angiogenesis. Adv Cancer Res 19:331358

49. Folkman J (1975) Tumor angiogenesis: a possible control point in tumor growth. Ann Intern Med 82:96-100

50. Brem H, Folkman J (1975) Inhibition of tumor angiogenesis mediated by cartilage. J Exp Med 141:427-439

51. Wolf JE, Hubler WR (1975) Tumour angiogenic factor associated with subcutaneous lymphoma. $\mathrm{Br} \mathrm{J}$ Dermatol 92:273-277

52. Wolf JE Jr, Hubler WR Jr (1975) Tumor angiogenic factor and human skin tumors. Arch Dermatol 111:321-327

53. Folkman J, Cotran R (1976) Relation of vascular proliferation to tumor growth. Int Rev Exp Pathol 16:207-248

54. Brem S (1976) The role of vascular proliferation in the growth of brain tumors. Clin Neurosurg 23:440-453

55. Falterman KW, Ausprunk H, Klein MD (1976) Role of tumor angiogenesis factor in maintenance of tumor-induced vessels. Surg Forum 27:157-159

56. Gospodarowicz D (1976) Humoral control of cell proliferation: the role of fibroblast growth factor in regeneration, angiogenesis, wound healing, and neoplastic growth. Prog Clin Biol Res 9:1-19

57. Kessler DA, Langer RS, Pless NA et al (1976) Mast cells and tumor angiogenesis. Int J Cancer 18:703-709

58. Auerbach R, Kubai L, Sidky Y (1976) Angiogenesis induction by tumors, embryonic tissues, and lymphocytes. Cancer Res 36:3435-3440

59. Sidky YA, Auerbach R (1976) Lymphocyte-induced angiogenesis in tumor-bearing mice. Science 192:1237-1238

60. Jones PA, De Clerck YA (1982) Extracellular matrix destruction by invasive tumor cells. Cancer Metastasis Rev 1:289-317

61. Pauli BU, Schwartz DE, Thonar EJ, Kuettner KE (1983) Tumor invasion and host extracellular matrix. Cancer Metastasis Rev 2:129-152

62. Gospodarowicz D (1983) Growth factors and their action in vivo and in vitro. J Pathol 141:201-233

63. Ruoslahti E (1984) Fibronectin in cell adhesion and invasion. Cancer Metastasis Rev 3:43-51

64. Bissell MJ, Barcellos-Hoff MH (1987) The influence of extracellular matrix on gene expression: is structure the message? J Cell Sci Suppl 8:327-343

65. Delinassios JG (1987) Fibroblasts against cancer cells in vitro. Anticancer Res 7:1005-1010

66. Van den Hooff (1988) A Stromal involvement in malignant growth. Adv Cancer Res 50:159-196
67. Schor SL, Haggie JA, Durning P et al (1986) Occurrence of a fetal fibroblast phenotype in familial breast cancer. Int $\mathrm{J}$ Cancer 37:831-836

68. Schmidt A, Weber OF (2006) In memoriam of Rudolf Virchow: a historical retrospective including aspects of inflammation, infection and neoplasia. Contrib Microbiol 13:1-15

69. Balkwill F, Charles KA, Mantovani A (2005) Smoldering and polarized inflammation in the initiation and promotion of malignant disease. Cancer Cell 7:211-217

70. Mantovani A, Sica A, Locati M (2005) Macrophage polarization comes of age. Immunity 23:344-346

71. Condeelis J, Pollard JW (2006) Macrophages: obligate partners for tumor cell migration, invasion, and metastasis. Cell 124:263266

72. Tan TT, Coussens LM (2007) Humoral immunity, inflammation and cancer. Curr Opin Immunol 19:209-216

73. Witz IP (2008) Yin-yang activities and vicious cycles in the tumor microenvironment. Cancer Res 68:9-13

74. Mantovani A, Bottazzi B, Colotta F et al (1992) The origin and function of tumor-associated macrophages. Immunol Today $13: 265-270$

75. Brigati C, Noonan DM, Albini A et al (2002) Tumors and inflammatory infiltrates: Friends or foes? Clin Exp Metastasis 19:247-258

76. Dirkx AE, Oude Egbrink MG, Wagstaff J et al (2006) Monocyte/ macrophage infiltration in tumors: Modulators of angiogenesis. J Leukoc Biol 80:1183-1196

77. Lamagna C, Aurrand-Lions M, Imhof BA (2006) Dual role of macrophages in tumor growth and angiogenesis. J Leukoc Biol 80:705-713

78. Talmadge JE, Donkor M, Scholar E (2007) Inflammatory cell infiltration of tumors: Jekyll or Hyde. Cancer Metastasis Rev 26:373-400

79. Whitworth PW, Pak CC, Esgro J et al (1990) Macrophages and cancer. Cancer Metastasis Rev 8:319-351

80. Pak CC, Fidler IJ (1991) Molecular mechanisms for activated macrophage recognition of tumor cells. Semin Cancer Biol 2:189-195

81. Lin EY, Pollard JW (2004) Role of infiltrated leucocytes in tumour growth and spread. Br J Cancer 90:2053-2058

82. Pollard JW (2004) Tumour-educated macrophages promote tumour progression and metastasis. Nat Rev Cancer 4:71-78

83. Mantovani A, Schioppa T, Porta C et al (2006) Role of tumorassociated macrophages in tumor progression and invasion. Cancer Metastasis Rev 25:315-322

84. Pawelek J, Chakraborty A, Lazova R et al (2006) Co-opting macrophage traits in cancer progression: A consequence of tumor cell fusion? Contrib Microbiol 13:138-155

85. Allavena P, Sica A, Solinas G et al (2008) The inflammatory micro-environment in tumor progression: The role of tumorassociated macrophages. Crit Rev Oncol Hematol 66:1-9

86. Gazzaniga S, Bravo AI, Guglielmotti A et al (2007) Targeting tumor-associated macrophages and inhibition of MCP-1 reduce angiogenesis and tumor growth in a human melanoma xenograft. J Invest Dermatol 127:2031-2041

87. Schwantke N, Le Bouffant F, Dorée M et al (1985) Protein kinase $\mathrm{C}$ : properties and possible role in cellular division and differentiation. Biochimie 67:1103-1110

88. Cohen I, Van der Kloot W (1985) Calcium and transmitter release. Int Rev Neurobiol 27:299-336

89. Stryer L, Bourne HR (1986) G proteins: a family of signal transducers. Annu Rev Cell Biol 2:391-419

90. Bregman MD, Sipes NJ (1986) Transformation-related growth factors and their receptors. Int J Cell Cloning 4:224-236

91. Bradshaw TK (1986) Cell transformation: the role of oncogenes and growth factors. Mutagenesis 1:91-97 
92. Klausner RD, Patel MD, O’Shea JJ et al (1987) Phosphorylation of the $\mathrm{T}$ cell antigen receptor: multiple signal transduction pathways. J Cell Physiol Suppl 5:49-51

93. Castagna M (1987) Phorbol esters as signal transducers and tumor promoters. Biol Cell 59:3-13

94. Bockenstedt LK, Goldsmith MA, Koretzky GA et al (1987) The activation of T lymphocytes. Rheum Dis Clin North Am 13:411-430

95. Lockwood AH, Murphy SK, Se B et al (1987) Cellular signal transduction and the reversal of malignancy. J Cell Biochem $33: 237-255$

96. Linch DC, Wallace DL, O'Flynn K (1987) Signal transduction in human T lymphocytes. Immunol Rev 95:137-159

97. Bourne HR (1988) Signals past, present, and future. Cold Spring Harb Symp Quant Biol 53:1019-1031

98. Hunter T, Angel P, Boyle WJ et al (1988) Targets for signaltransducing protein kinases. Cold Spring Harb Symp Quant Biol $53: 131-142$

99. Goldsmith MA, Weiss A (1988) Generation and analysis of a Tlymphocyte somatic mutant for studying molecular aspects of signal transduction by the antigen receptor. Ann N Y Acad Sci 546:91-103

100. Weinstein IB (1988) Strategies for inhibiting multistage carcinogenesis based on signal transduction pathways. Mutat Res 202:413-420

101. Harris AL, Nicholson S (1988) Epidermal growth factor receptors in human breast cancer. Cancer Treat Res 40:93118

102. Liotta LA, Stracke ML (1988) Tumor invasion and metastases: biochemical mechanisms. Cancer Treat Res 40:223-238

103. Dillon SB, Verghese MW, Snyderman R (1988) Signal transduction in cells following binding of chemoattractants to membrane receptors. Virchows Arch B Cell Pathol Incl Mol Pathol 55:65-80

104. Blumberg DD, Comer JF, Higinbotham KG (1988) A Ca2+dependent signal transduction system participates in coupling expression of some cAMP-dependent prespore genes to the cell surface receptor. Dev Genet 9:359-369

105. Yuspa SH, Hennings H, Tucker RW et al (1988) Signal transduction for proliferation and differentiation in keratinocytes. Ann N Y Acad Sci 548:191-196

106. Roskelley CD, Desprez PY, Bissell MJ (1994) Extracellular matrix-dependent tissue-specific gene expression in mammary epithelial cells requires both physical and biochemical signal transduction. Proc Natl Acad Sci U S A 91:1237812382

107. Boudreau N, Myers C, Bissell MJ (1995) From laminin to lamin: regulation of tissue-specific gene expression by the ECM. Trends Cell Biol 5:1-4

108. Mazure NM, Chen EY, Yeh P et al (1996) Oncogenic Transformation and Hypoxia Synergistically Act to Modulate Vascular Endothelial Growth Factor Expression. Cancer Research 56:3436-3440

109. Halachmi E, Witz IP (1989) Differential tumorigenicity of $3 \mathrm{~T} 3$ cells transformed in vitro with polyoma virus and in vivo selection for high tumorigenicity. Cancer Res 49:23832389

110. Lochter A, Bissell MJ (1995) Involvement of extracellular matrix constituents in breast cancer. Semin Cancer Biol 6:165-173

111. Weaver VM, Fischer AH, Peterson OW et al (1996) The importance of the microenvironment in breast cancer progression: recapitulation of mammary tumorigenesis using a unique human mammary epithelial cell model and a three-dimensional culture assay. Biochem Cell Biol 74:833-851

112. Park CC, Bissell MJ, Barcellos-Hoff MH (2000) The influence of the microenvironment on the malignant phenotype. Mol Med Today 6:324-329
113. Sager R (1997) Expression genetics in cancer: shifting the focus from DNA to RNA. Proc Natl Acad Sci USA 94:952-955

114. Vogelstein B, Kinzler KW (2004) Cancer genes and the pathways they control. Nat Med 10:789-799

115. Cho-Chung YS, Clair T, Tortora G et al (1991) Suppression of malignancy targeting the intracellular signal transducing proteins of cAMP: the use of site-selective cAMP analogs, antisense strategy, and gene transfer. Life Sci 48:1123-1132

116. Lupu R, Lippman ME, William L (1993) The role of erbB2 signal transduction pathways in human breast cancer. Breast Cancer Res Treat 27:83-93

117. Cole K, Kohn E (1994) Calcium-mediated signal transduction: biology, biochemistry, and therapy. Cancer Metastasis Rev 13:31-44

118. Heimbrook DC, Oliff A (1998) Therapeutic intervention and signaling. Curr Opin Cell Biol 10:284-288

119. Adams J, Palombella VJ, Elliott PJ (2000) Proteasome inhibition: a new strategy in cancer treatment. Invest New Drugs 18:109-121

120. Chambers AF, MacDonald IC, Schmidt EE et al (2000) Clinical targets for anti-metastasis therapy. Adv Cancer Res 79:91-121

121. Talpaz M (2001) Interferon-alfa-based treatment of chronic myeloid leukemia and implications of signal transduction inhibition. Semin Hematol 38:22-27

122. Baselga J, Albanell J (2001) Mechanism of action of anti-HER2 monoclonal antibodies. Ann Oncol 12:S35-41

123. Demetri GD (2001) Targeting c-kit mutations in solid tumors: scientific rationale and novel therapeutic options. Semin Oncol 28:19-26

124. Yarden Y (2001) Biology of HER2 and its importance in breast cancer. Oncology 61:1-13

125. Rüegg C, Dormond O, Foletti A (2002) Suppression of tumor angiogenesis through the inhibition of integrin function and signaling in endothelial cells: which side to target? Endothelium 9:151-160

126. Baselga J (2002) Why the epidermal growth factor receptor? The rationale for cancer therapy. Oncologist 7:2-8

127. Ferrara N (2002) Role of vascular endothelial growth factor in physiologic and pathologic angiogenesis: therapeutic implications. Semin Oncol 29:10-14

128. Lin A, Karin M (2003) NF-kappaB in cancer: a marked target. Semin Cancer Biol 13:107-114

129. Mendelsohn J, Baselga J (2003) Status of epidermal growth factor receptor antagonists in the biology and treatment of cancer. J Clin Oncol 21:2787-2799

130. Klein S, Levitzki A (2009) Targeting the EGFR and the PKB pathway in cancer. Curr Opin Cell Biol 21:185-193

131. Linger RM, Keating AK, Earp HS et al (2008) TAM receptor tyrosine kinases: biologic functions, signaling, and potential therapeutic targeting in human cancer. Adv Cancer Res 100:35-83

132. Ashkenazi A (2008) Targeting the extrinsic apoptosis pathway in cancer. Cytokine Growth Factor Rev 19:325-331

133. Jakowlew SB (2006) Transforming growth factor-beta in cancer and metastasis. Cancer Metastasis Rev 25:435-457

134. Witz IP, Levy-Nissenbaum O (2006) The tumor microenvironment in the post-PAGET era. Cancer Lett. 242:1-10

135. Witz IP (2008) Tumor-microenvironment interactions: dangerous liaisons. Adv Cancer Res 100:203-229

136. Murphy G (2008) The ADAMs: signalling scissors in the tumour microenvironment. Nat Rev Cancer 8:929-941

137. Hu M, Polyak K (2008) Molecular characterisation of the tumour microenvironment in breast cancer. Eur $\mathrm{J}$ Cancer 44:2760-2765

138. Hanna E, Quick J, Libutti SK (2009) The tumour microenvironment: a novel target for cancer therapy. Oral Dis 15:8-17 
139. Lorusso G, Rüegg C (2008) The tumor microenvironment and its contribution to tumor evolution toward metastasis. Histochem Cell Biol 130:1091-1103

140. Shojaei F, Ferrara N (2008) Role of the microenvironment in tumor growth and in refractoriness/resistance to anti-angiogenic therapies. Drug Resist Updat 11:219-230

141. Whiteside TL (2008) The tumor microenvironment and its role in promoting tumor growth. Oncogene 27:5904-5912

142. Wikman H, Vessella R, Pantel K (2008) Cancer micrometastasis and tumour dormancy. APMIS 116:754-770

143. Rademakers SE, Span PN, Kaanders JH et al (2008) Molecular aspects of tumour hypoxia. Mol Oncol 2:41-53

144. Mendoza M, Khanna C (2009) Revisiting the seed and soil in cancer metastasis. Int J Biochem Cell Biol 41:1452-1462

145. Melnikova VO, Bar-Eli M (2009) Inflammation and melanoma metastasis. Pigment Cell Melanoma Res 22:257-267

146. Klymkowsky MW, Savagner P (2009) Epithelial-mesenchymal transition: a cancer researcher's conceptual friend and foe. Am J Pathol 174:1588-1593

147. Joyce JA, Pollard JW (2009) Microenvironmental regulation of metastasis. Nat Rev Cancer 9:239-252

148. Richmond A, Yang J, Su Y (2009) The good and the bad of chemokines/chemokine receptors in melanoma. Pigment Cell Melanoma Res 22:175-186

149. Anton K, Glod J (2009) Targeting the tumor stroma in cancer therapy. Curr Pharm Biotechnol 10:185-191
150. Zumsteg A, Christofori G (2009) Corrupt policemen: inflammatory cells promote tumor angiogenesis. Curr Opin Oncol 21:60-70

151. Pittet MJ (2009) Behavior of immune players in the tumor microenvironment. Curr Opin Oncol 21:53-59

152. Smalley KS, Herlyn M (2009) Integrating tumor-initiating cells into the paradigm for melanoma targeted therapy. Int $\mathrm{J}$ Cancer 124:1245-1250

153. Mbeunkui F, Johann DJ Jr (2009) Cancer and the tumor microenvironment: a review of an essential relationship. Cancer Chemother Pharmacol 63:571-582

154. Polyak K, Haviv I, Campbell IG (2009) Co-evolution of tumor cells and their microenvironment. Trends Genet 25:30-38

155. Padua D, Massagué J (2009) Roles of TGFbeta in metastasis. Cell Res 19:89-102

156. Somasundaram R, Herlyn D (2009) Chemokines and the microenvironment in neuroectodermal tumor-host interaction. Semin Cancer Biol 19:92-96

157. Pfeifer AC, Timmer J, Klingmüller U (2008) Systems biology of JAK/STAT signalling. Essays Biochem 45:109-120

158. Schrattenholz A, Soskić V (2008) What does systems biology mean for drug development? Curr Med Chem 15: $1520-1528$

159. Li H, Sun Y, Zhan M (2009) Exploring pathways from gene coexpression to network dynamics. Methods Mol Biol 541:249 267 